DOI: http://dx.doi.org/10.21123/bsj.2020.17.3(Suppl.).1071

\title{
Removal of Amoxicillin from Water by Adsorption on Water Treatment Residues
}

\author{
Mahmood M. Barbooti ${ }^{* 1}$ \\ Sarah H. Zahraw \\ ${ }^{1,2}$ Chemistry Division, Applied Science Department, University of Technology, Baghdad, Iraq. \\ *Corresponding author: brbt2m@gmail.com, \\ *ORCID ID: http://orcid.org/0000-0002-9793-7400 \\ ${ }^{2}$ sarahhadi204@gmail.com
}

Received 8/12/2019, Accepted 19/2/2020, Published 8/9/2020

\begin{abstract}
:
The presence of residual antibiotics in water results in the development of antibiotics resistant genes. The available wastewater treatment systems are not capable of removing such antibiotics from sewage. Thus, antibiotics need to be removed before the discharge of wastewater. Adsorption is among the promising techniques for the wastewater treatment to aid the removal of a wide range of organic and inorganic pollutants. The present work is a contribution to the search for an economical method for the removal of low concentrations of amoxicillin (AMX) from water by adsorption on water treatment residue, WTR, taken from a local drinking water facility. The chemical composition and the adsorptive characteristics of the material were first evaluated using energy dispersive spectroscopy, EDS, and sorption of methylene blue, respectively. The porous character of the sorbent was modified by ignition. The application of the WTR for the adsorption of AMX was studied under various operating conditions including sorbent dosage, 2-20 g/L at room temperature; contact time 30-240 min.; and initial concentration range of the antibiotic, 0.00004-0.00012 M. facility. To aid the experimental work, statistical software was employed to design the experiments and evaluation of the results. Graphical and mathematical relationships have been established for the adsorption efficiency with the operating conditions. The adsorption capacity was calculated from the plot of the adsorbed drug against the sorbent content and found to be $19.966 \mu \mathrm{mol} / \mathrm{g}$ WTR. The sorption efficiency depends on the initial concentration and being better at low concentration $(0.00004 \mathrm{M})$ and equilibrium time (within 100 mins.). The optimum conditions of the adsorption are: AMX Concentration, $0.00004 \mathrm{M}$; Contact time. The optimum conditions of the adsorption are: AMX Concentration, $0.00004 \mathrm{M}$; Contact time, $90 \mathrm{~min}$., and WTR content of $15.5 \mathrm{~g} / \mathrm{L}$ to give removal efficiency of $89.2 \%$.
\end{abstract}

Key words: Adsorption, Amoxicillin, Antibiotic removal, Experimental design, Methylene blue Water treatment residue.

\section{Introduction:}

Antibiotics are uniquely effective and selective on pathogenic bacteria, in both human and veterinary medicine for therapeutic treatment of infections related diseases, (1). The antibiotic usage increased rapidly and concern focused on their residues in the environment as it can induce antibiotic resistant genes from extended exposure at relatively low concentrations (2). The residues of human and veterinary antibiotics have been detected in environmental samples from soil and more specifically in water $(3,4)$. The exposure to antibiotics at the parts per million levels may be risky on aquatic organism's survival, body weight and growth (5).

Urban wastewater treatment plants are likely to be hotspots for the release of antibiotics in the natural environment (6). Thus, antibiotics are recognized as emerging environment contaminants (7), hence antibiotics are regarded as toxic and hazardous chemicals (8). Partial removal of antibiotics may be performed by adsorption on river sediments and the process is influenced by their iron and organic contents (9). It is important, therefore, to remove antibiotic residues before discharging wastewater 
into the environment but the process is usually costly. Case studies that involved the search for providing cheap and efficient methods and materials to affect the cost of antibiotic removal are urgently needed $(10,11)$. Processes are advanced oxidation such as catalytic ozonation $\left(\mathrm{TiO}_{2} / \mathrm{O}_{3}\right.$ in dark), photocatalytic oxidation $\left(\mathrm{TiO}_{2} / \mathrm{UVA} / \mathrm{O}_{2}\right)$, and photocatalytic ozonation $\left(\mathrm{TiO}_{2} / \mathrm{UVA} / \mathrm{O}_{3}\right)$. The methods can convert antibiotic molecules into simple compounds or even mineralize them completely. However, the relative costs and outcomes of these processes are very expensive $(12,13)$. Even though, they are difficult to maintain regarding the total removal of compounds including antibiotics at industrial scale. Thus, physicochemical methods are proving to be highly suitable treatment option for organic contaminants $(14,15)$. Adsorption process is very efficient, simple to be designed and operated; and it is relatively inexpensive (16 - 18). The efficiency of adsorption processes is highly affected by the type of adsorbent, adsorbate properties and the compositions of waste stream (19). Clay minerals, e.g. bentonite, montmorillonite, and kaolinite have a high surface area and pore volume and may act as adsorbent for the remediation of antibiotics from water and wastewater. Montmorillonite proved an excellent adsorbent for the removal of oxtetracycline from water (17). Activated carbon, AC, gave better adsorption efficiency than bentonite regarding amoxicillin removal from real wastewater. However, neither of the two adsorbents could completely remove amoxicillin due to the sorption competition from other substances which were also present in the wastewater (19). Balarak, et al., (20) used palm bark as adsorbent for AMX from aqueous solutions and reported an adsorption capacity of $35 \mathrm{mg} / \mathrm{g}$. Tovar, et al., (21) used AC impregnated with $\mathrm{ZnCl}_{2}$ as an adsorbent for the removal of amoxicillin from aqueous solution at a removal rate of $77.4 \%$. The efficiency of the removal was $60-70 \%$ for a 200 $\mathrm{mg} / \mathrm{L}$ solution of amoxicillin using a dose of 600 $\mathrm{mg} / \mathrm{L}$ adsorbent. Both oxidation and adsorption techniques have their advantages and limitations. Boukhelkhal, et al., (22) utilized wheat grains as adsorbent to remove amoxicillin antibiotic from wastewater for a maximum removal percentage of $84 \%$ for amoxicillin on wheat grain treated with $20 \%$ tartaric acid. Different clay materials were evaluated by Maia, et al., (23) for the removal of amoxicillin and other medicines like caffeine, propranolol, and diclofenac sodium from aqueous solutions and gave removal efficiency varied between 23-98 \% for amoxicillin. Song, (24) succeeded in the removal of amoxicillin on novel nano (mesoporous silica supported polymers), which was characterized by large surface area and amendable surface characteristics. Graphene oxide (GO) and magnetite GO were also employed for the adsorption of amoxicillin by Moradi, (25).

Many authors used cheap adsorbents to ensure the economy of the process like slag (magnetite) and bentonite clay (Maichin, et al., (26), sludge (De Gisi, et al, (27), and aluminum-based WTR (Lee et al, (28). Zhou and Haynes, (29) reviewed the effect of working parameters on the sorption efficiency of heavy metal ions on WTR. Punimaya, et al. (30), evaluated the arsenite As (III) and arsenate $[\mathrm{As}(\mathrm{V})]$ sorption by $\mathrm{Fe}$ - and $\mathrm{Al}$-based WTR was as a function of the particle size at different $\mathrm{pH}$ values. Suda et al., (31) used WTR to stabilize arsenic in flooded soils and attenuate arsenic uptake by rice (Oryza sativaL.) plants. Drinking water treatment residual was characterized by Zhao, et al., (32) to adsorb chlorpyrifos. The use of Ca-WTR was studied as a cost-effective remediation method for the $\mathrm{Cu}$-contaminated soils without affecting citrus production (33). Barbooti, et al., (34) utilized the WTR in the control of phosphate levels in irrigation water.

The aim of the present work is the evaluation of WTR as a sorbent with the aid of methylene blue, $\mathrm{MB}$, adsorption as a model compound. The WTR will be then utilized for the removal of AMX from water under various operating conditions like initial concentration, contact time and the amount of the adsorbent. Experimental design program was employed for the design and evaluation of results.

\section{Materials and Methods:}

The AMX (molecular mass $365.4 \mathrm{~g} / \mathrm{mol}$ ) was $98 \%$ pure materials supplied from The State Drug Industries State Company, Samarra, Iraq and used without further purification. The MB was analytical reagent from Riedel de Haen, Germany. The water treatment residue, WTR was obtained from a local drinking water facility (Wathba Station, Utafiyah, Baghdad) during the maintenance period. The composition will be studied in details after some preparation. It was naturally dried and ground in an agate mortar to pass $0.06 \mathrm{~mm}$ mesh. The material was further activated by thermal treatment in a muffle furnace at $650^{\circ} \mathrm{C}$ and the

\section{Apparatus}

The concentration of methylene blue and AMX solutions were measured by spectral absorption on EMC Lab, GMBH, Germany, (UV1100) spectrophotometer. The full spectra were recorded on a Shimadzu, UV/Vis spectrometer. Energy dispersive spectral, EDS, measurements 
were made on EDS instrument from FEI company, Netherland. The sorption experiments involved the shaking of the samples with Genex, shaker, Florida, USA.

\section{Procedures}

\section{Calibration graphs}

The calibration graph for the spectral determination of $\mathrm{MB}$ was prepared by serial dilution of the stock solution within the range of $0.000004 .0-0.000006 \mathrm{M}$. The absorbance was measured at $229 \mathrm{~nm}$ as the wavelength of maximum absorption over a range of concentration 0.00004$0.00012 \mathrm{M}$. This corresponds to $14.6-36.5 \mathrm{mg} / \mathrm{L}$.

\subsubsection{Preparation and evaluation of WTR}

The WTR sample was air-dried for $72 \mathrm{~h}$ at room temperature, dried at $105^{\circ} \mathrm{C}$. It was then homogenized, grinded and sieved to end up with three portions of $1.18,0.075$, and $0.07 \mathrm{~mm}$ particle sizes. The $\mathrm{pH}$ was measured for the $1: 2.5 \mathrm{w} / \mathrm{v}$ (WTR: water) suspension for $1 \mathrm{~h}$. To decompose the organic matter (OM), a known weight of WTR was placed in porcelain crucible and ignited to $650^{\circ} \mathrm{C}$ by laboratory Furnace. The composition of WTR was evaluated before and after ignition using the EDS. The adsorption properties of WTR were evaluated by studying the removal of methylene blue (MB) from water. In four plastic containers, $20-\mathrm{ml}$ aliquots of MB solutions of $0.0002 \mathrm{M}$ were placed together with four different WTR amounts in plastic containers, capped, sealed with Parafilm and shaken for two hours at a speed of $250 \mathrm{rpm}$. The residual $\mathrm{MB}$ was estimated by referring to the calibration graph.

\section{The Cation Exchange Capacity, Determination:}

Dye cations like MB will mainly be adsorbed by cation exchange (35). Thus, the MB adsorption depends on the exchangeable cations of the sorbent. The Cation Exchange Capacity, CEC, was determined using the procedure used by Barbooti, et al., (34) employing MB adsorption as indicator material.

\section{Surface Area Determination:}

The specific surface area can also be calculated with MB adsorption when the sorbent surface area per charge corresponds with the area of the methylene blue cation of $130 \AA^{2}$ (35). The details of the procedure were given in a recent application for the removal of phosphate from water (34)

\section{Experimental Design:}

Experimental design (Statistica) was used to study the effects of experimental variables (operating parameters), at various levels simultaneously on the adsorption of the selected antibiotics on the basis of statistical treatment to determine the optimum conditions (36). The details of the approach were recently described regarding the removal of nickel ions from water by adsorption on certain composite (37). It saves time and efforts and at the same time measures the precision of the process. The response can be estimated at any set of conditions when the selected model fits with the practical results. The operating conditions for AMX adsorption on WTR are given in Table 1.

Table 1. Real experimental parameters conditions for adsorption of AMX on WTR.

\begin{tabular}{llll}
\hline No. & $\begin{array}{l}\text { Contact } \\
\text { Time, min }\end{array}$ & $\begin{array}{l}\text { Sorbent } \\
\text { Dose, g/L }\end{array}$ & $\begin{array}{l}\text { Amoxicillin } \\
\text { Concentration, M }\end{array}$ \\
\hline 1 & 105 & 6.5 & 0.00006 \\
2 & 105 & 6.5 & 0.0001 \\
3 & 105 & 15.5 & 0.00006 \\
4 & 105 & 15.5 & 0.0001 \\
5 & 195 & 6.5 & 0.00006 \\
6 & 195 & 6.5 & 0.0001 \\
7 & 195 & 15.5 & 0.00006 \\
8 & 195 & 15.5 & 0.00008 \\
9 & 60 & 11 & 0.00008 \\
10 & 240 & 11 & 0.00008 \\
11 & 150 & 2 & 0.00004 \\
12 & 150 & 20 & 0.00012 \\
13 & 150 & 11 & 0.00008 \\
14 & 150 & 11 & 0.00008 \\
15 & 150 & 11 & 0.00008 \\
16 & 150 & 11 & 0.00008 \\
17 & 150 & 11 & 0.00008 \\
18 & 150 & 11 & 0.00008 \\
\hline
\end{tabular}

\section{Preliminary experiments}

A set of adsorption experiments was conducted in duplicate on a fixed AMX concentration solution $(0.00006 \mathrm{M})$ with varying amounts of WTR contents $(0.2,0.35,0.4,0.55,0.7$, 0.85 and $1.0 \mathrm{~g}$ ) placed in $60-\mathrm{mL}$ capacity container and $1.0 \mathrm{~mL}$ of $\mathrm{KCl}$ solution to ensure the necessary ionic strength in the solution. The total volume was made up to $50 \mathrm{~mL}$ by deionized water. The containers were capped and further sealed by Parafilm. The containers were shaken for $180 \mathrm{~min}$ at $250 \mathrm{rpm}$. The residual concentrations were analyzed by UV absorption at $229 \mathrm{~nm}$. The absorbance measurements were checked against a blank to ensure freedom from interferences.

\section{Results and Discussion Evaluation of the WTR}

The ignition of the WTR resulted in a loss of $16.56 \%$, which is associated with the thermal decomposition of the organic matter content and the possible decomposition of some carbonates. The 
color of the material changed from light grey to pink. The chemical composition of the material before and after the ignition confirms such suggestion. The changes in the elemental contents are listed in Table 2. A clear increase in the calcium content and a decrease of the oxygen could be observed and disappearance of the carbon signal. Carbon is related to the calcium carbonate and the organic matter content of the WTR. The composition of WTR comprised a mixture of various inorganic elements. The $\mathrm{Ca}$ and $\mathrm{Al}$ contents were reported by Ippolito et al. (2003) (39) to be present in $\mathrm{Al}-\mathrm{WTR}$, whereas the presence of $\mathrm{Al}, \mathrm{Fe}$, $\mathrm{P}, \mathrm{Si}, \mathrm{Ca}$, and $\mathrm{Na}$ in $\mathrm{Al}-$ and $\mathrm{Fe}-\mathrm{WTR}$ as given by Makris et al. (40). The thermal activation results in enhancement of the power of the adsorptive materials and gives the porous structure due to interlayer spaces collations (41). Moreover, some chemical activation of adsorptive materials generated a more porous structure as well as more oxygenated functional groups on their surfaces than thermal activation only (41).

Table 2. Elemental composition of the water treatment residue before and after the ignition.

\begin{tabular}{|c|c|c|}
\hline \multirow[t]{2}{*}{ Element } & \multicolumn{2}{|c|}{ Weight Percentage } \\
\hline & Before burning & After burning \\
\hline $\mathrm{O}$ & 48.49 & 41.50 \\
\hline $\mathrm{Si}$ & 15.73 & 21.51 \\
\hline $\mathrm{Ca}$ & 11.38 & 13.25 \\
\hline $\mathrm{C}$ & 7.27 & ----- \\
\hline $\mathrm{Al}$ & 5.66 & 7.65 \\
\hline $\mathrm{Fe}$ & 3.23 & 5.63 \\
\hline $\mathrm{Mg}$ & 2.27 & 3.98 \\
\hline $\mathrm{K}$ & 1.58 & 1.12 \\
\hline $\mathrm{Na}$ & 0.10 & 0.16 \\
\hline
\end{tabular}
determined by plotting the adsorbed amount of MB (319.85 g/mole) against the corresponding WTR content as shown in Fig. 1. From the slope of the plot, the CEC value was calculated and found to be $20.63 \mu \mathrm{mole} / \mathrm{g}$. This corresponds to $6.6 \mathrm{mg} / \mathrm{g}$. Sorbents with smaller particle size gave higher CEC values (30).

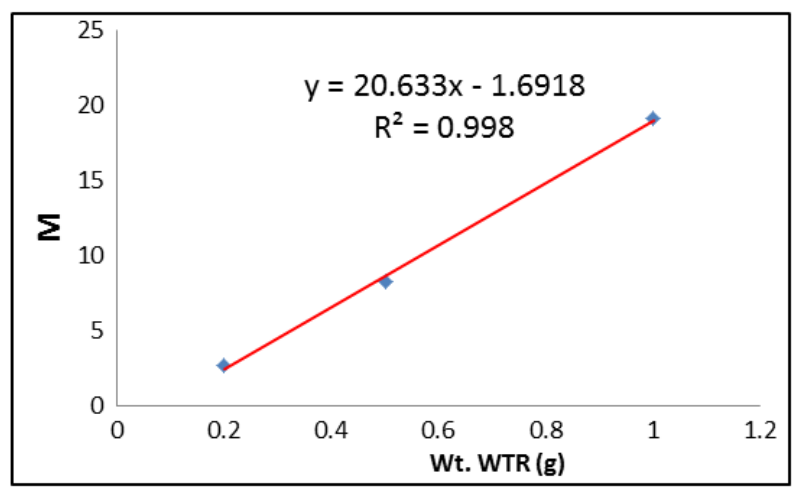

Figure 1. Cation exchange capacity plot for the water treatment residue.

\section{Preliminary experiments}

A sets of sorption experiments were carried using a range of WTR amounts 2-20 g/L) in contact with the same aliquot of AMX $(0.00006$ $\mathrm{M})$ and shaken for 120 mins. The adsorption capacity was estimated over a range of WTR contents by plotting the adsorbed concentration against quantity of the WTR (Fig. 2). The slope of the plot represents the average adsorption capacity. The estimated capacity for AMX was 19.966 $\mu \mathrm{mol} \mathrm{AMX/g} \mathrm{WTR.}$

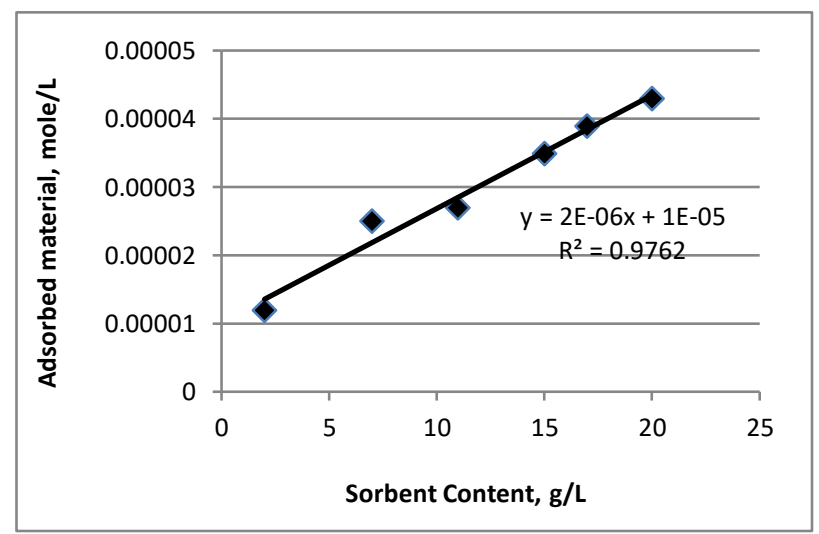

Figure 2. Determination of adsorption capacity of the amoxicillin.

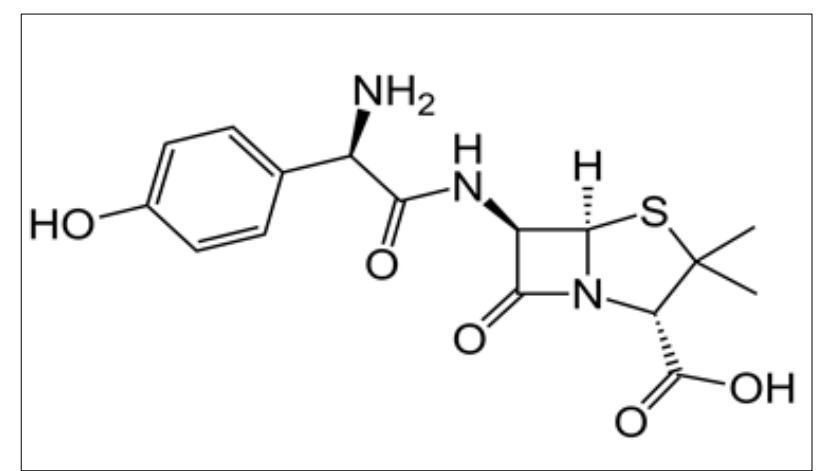

Figure 3. The chemical composition of the amoxicillin.

The chemical composition of AMX (Fig. 3 ) indicates the existence of two $\mathrm{OH}$ and two $\mathrm{NH}_{2}$ groups. Thus, the interaction was mostly through lone pairs of electrons in the two materials.

\section{Amoxicillin Adsorption on WTR}

Experimental design results

The adsorption efficiency values were calculated using eq. 1

$\mathrm{Eff} \%=\left(\mathrm{C}_{0}-\mathrm{C}_{\mathrm{i}}\right) / \mathrm{C}_{0}$

Where, $\mathrm{C}_{0}$ is the initial AMX concentration and $\mathrm{C}_{\mathrm{i}}$ is the AMX equilibrium concentration. The results of the adsorption efficiency of AMX on the WTR were calculated at various equilibrium times, initial AMX concentration and WTR contents, were 
the input. The experimental design program used the data of Table 1 together with the corresponding sorption efficiency to estimate the coefficients of the response equation (2) relating the efficiency with the experimental parameters:

Eff $\%=a_{0}+a_{1} * x_{1}+a_{2} * x_{2}+a_{3} * x_{3}+a_{4} * x_{1} * x_{2}+a_{5} * x_{1} * x_{3}$ $+a_{6} x_{2} * x_{3}+a_{7} * X_{1}{ }^{2}+a_{8} * x_{2}^{2}+a_{9} x_{3}^{2} \ldots \ldots$ (2),

where $X_{1}, X_{2}$, and $X_{3}$ represent the equilibration time $(\mathrm{min})$, the sorbent content $(\mathrm{g} / \mathrm{L})$ and initial AMX concentration (M), respectively. The coefficients (a's) were taken directly from the program output. The numerical values of the coefficients represent a direct proof on the dependence of the sorption efficiency on the specific parameters (Table 3).

Table 3. the coefficients of equation (2).

\begin{tabular}{ccccc}
\hline $\mathrm{a}_{0}$ & $\mathrm{a}_{1}$ & $\mathrm{a}_{2}$ & $\mathrm{a}_{3}$ & $\mathrm{a}_{4}$ \\
\hline-6.7 & 0.5 & 7.2 & 90416 & 0 \\
$\mathrm{a}_{5}$ & $\mathrm{a}_{6}$ & $\mathrm{a}_{7}$ & $\mathrm{a}_{8}$ & $\mathrm{a}_{9}$ \\
537.4 & -29366 & 0 & -0.2 & 0.1 \\
\hline
\end{tabular}

The zero value of the $a_{4}$ reflects the negligible interaction between equilibrium times with WTR dosage. The negative value of $\left(a_{6}\right)$ coefficient gave a clear evidence that concentration has a negative interaction with the sorption efficiency. Further, the zero value of the $\left(a_{7}\right)$ indicates the independence of sorption efficiency with the square of the equilibrium time and thus only linear correlation exists with time. After the AMX solution was equilibrated with the WTR powder for the predetermined time, the residual antibiotic concentration was determined by spectral absorption at $229 \mathrm{~nm}$. The adsorption efficiency was calculated for each specimen using the relation (Equation 3):

Eff $\%=-6.7+0.5 * \mathrm{X}_{1}+7.2 * \mathrm{X}_{2}+90416.4 * \mathrm{X}_{3}+$ $537.4 * \mathrm{X}_{1} * \mathrm{X}_{3}-29366.2 * \mathrm{X}_{2} * \mathrm{X}_{3}-0.2 * \mathrm{X}_{2}^{2}+0.1 \mathrm{X}_{3}{ }^{2} \ldots$ (3)

\section{Effect of sorbent content}

Figure 4 shows the effect of the sorbent content on the sorption efficiency, at fixed AMX concentration of $0.00008 \mathrm{M}$ after various contact times (30 - 120 minutes). The sorption efficiency showed an increase as the sorbent content increase up to a value of $11.0 \mathrm{~g} / \mathrm{L}$. Also, longer equilibrium time results in higher sorption efficiency.

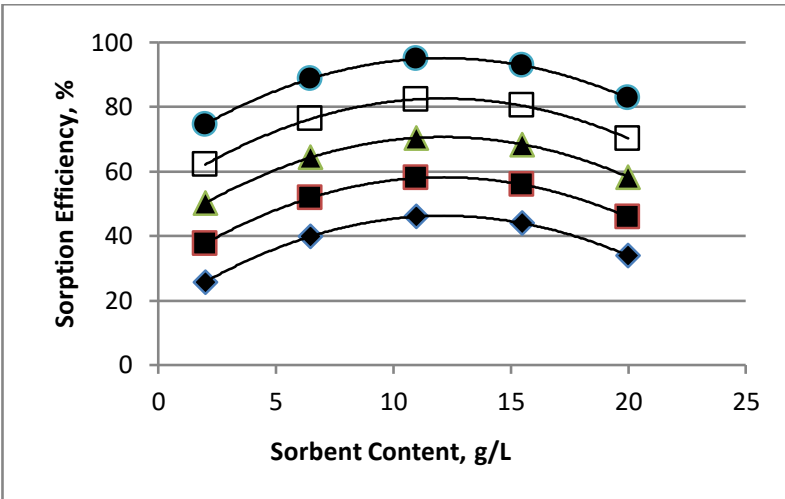

Figure 4. Effect of the WTR content on the sorption efficiency of $0.00008 \mathrm{M}$ AMX after 60 $(\diamond), 75(\square), 90(\Delta), 105(\square)$ and 120 minutes $(\odot)$ contact time.

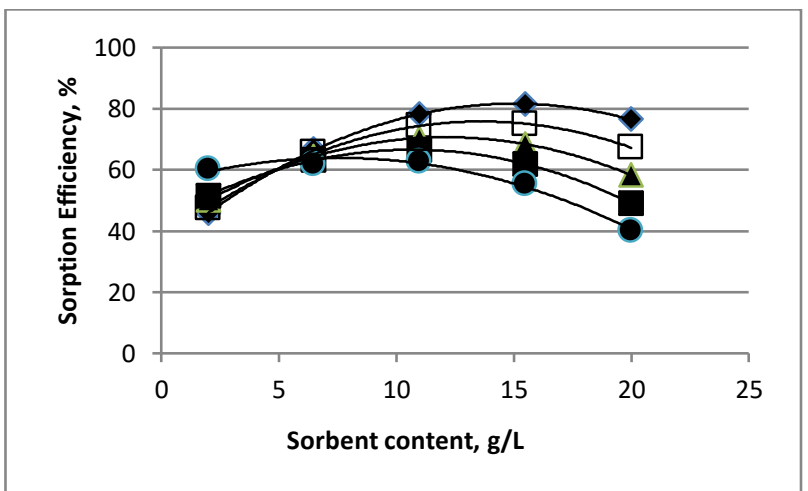

Figure 5. Effect of WTR content on the sorption efficiency after 90 min contact time and for:

AMX initial concentrations. $0.00004(\Theta) ; 0.00006$ $(\square) ; 0.00008(\triangle) ; 0.00010(\square)$, and $0.00012 \mathrm{M}(\diamond)$.

Figure 5 shows the effect of sorbent content on the sorption efficiency at a fixed equilibration time for 90 min and various AMX concentrations. The sorption efficiency exhibited a significant increase as the sorbent content increases until a maximum value is obtained at $15.5 \mathrm{~g} / \mathrm{L}$. However, the sorption process decreases significantly with the increase of the concentration. Higher concentration resulted in a competition between the AMX molecules towards the active sites of the sorbent (24).

\section{Effect of Equilibrium time}

Figure 6 shows the effect of equilibrium time on the sorption efficiency at a fixed AMX concentration of $0.00008 \mathrm{M}$ and various sorbent contents. The sorption efficiency linearly increases as the equilibrium time increases at all sorbent content values. Again the sorbent content of 11-15.5 $\mathrm{g} / \mathrm{L}$ gave the highest response $(92-94 \%)$. For the highest sorbent content, the efficiency dropped down to $82.7 \%$. 


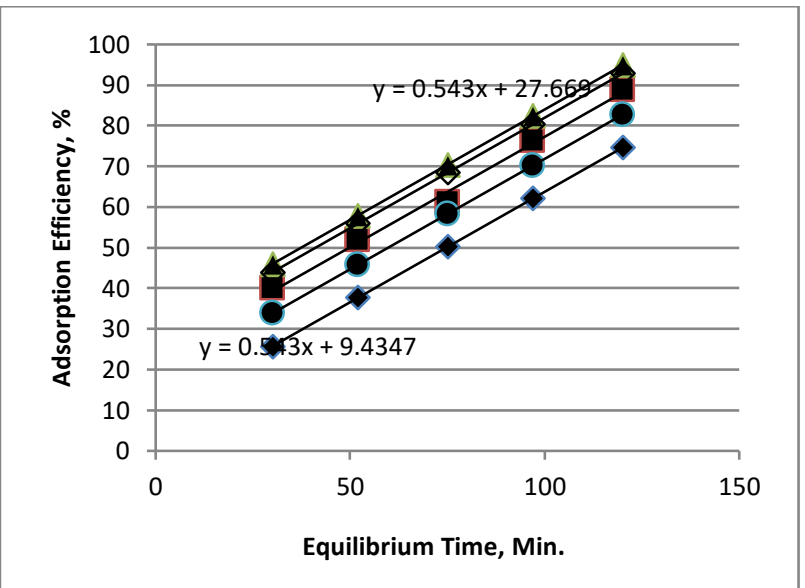

Figure 6. Effect of equilibrium time on sorption efficiency of $0.00008 \mathrm{M}$ AMX concentration on 2

$(\diamond), 6.5(\square), 11(\triangle), 15.5(\diamond)$ and $20 \mathrm{~g} / \mathrm{L}$ WTR content $(\Theta)$.

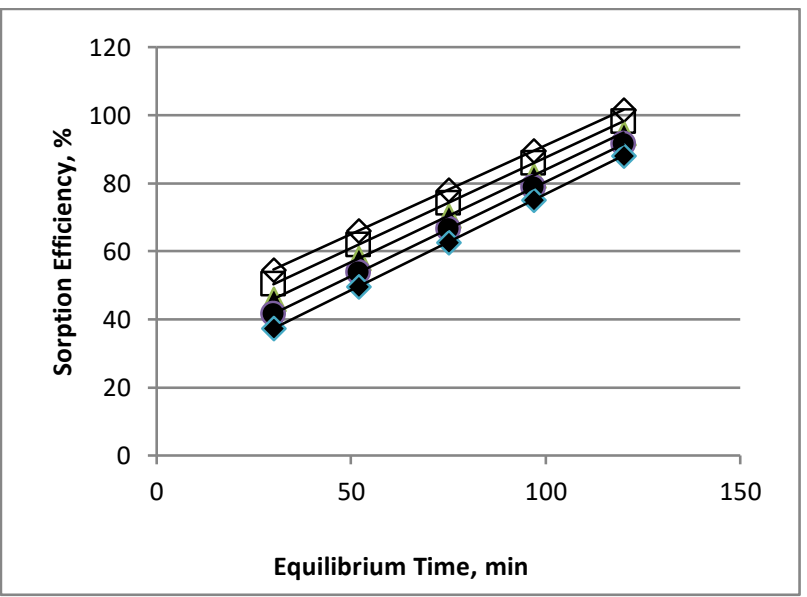

Figure 7. Effect of equilibrium time on AMX sorption efficiency on $11 \mathrm{~g} / \mathrm{L}$ WTR for initial concentration of $0.00004(\diamond) ; 0.00006(\square)$; $0.00008(\Lambda) ; 0.0001(\odot)$, and $0.00012 \mathrm{M}(\diamond)$.

Figure 7and 8 shows the effect of equilibrium time on the sorption efficiency at a fixed sorbent content of $11 \mathrm{~g} / \mathrm{L}$ and various AMX concentrations. The sorption efficiency linearly increases as the contact time between the AMX molecules and the WTR sorbent for various AMX concentration levels. Although the 120 minutes gave a sorption efficiency as high as $100 \%$; the 90 minutes will be taken as the optimum contact time as the efficiency rapidly drops beyond 120 minutes. The results are more stable and repeatable at 90-100 minutes time. This is in agreement with the results of Balarak, et al., (20) who used adsorption onto palm bark biomass. The significance of adsorption time duration is not yet solved. Some authors (17) reported an overnight contact between sorbent with solution (17). Others used a 2-6 hours contact time and reported that longer time may cause desorption of the pollutant (39).

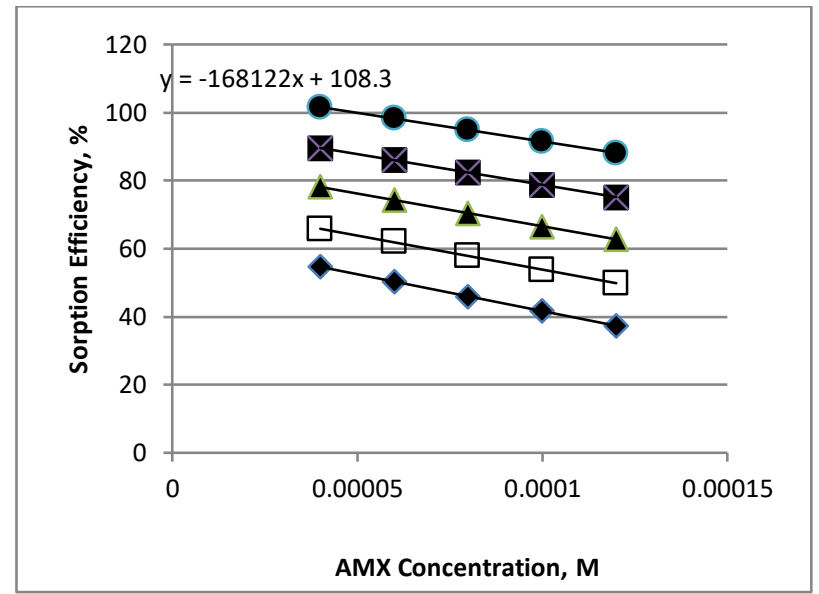

Figure 8. Effect of AMX concentration of the sorption efficiency on $11 \mathrm{~g} / \mathrm{L}$ sorbent after $60(\diamond)$; $75(\square) ; 90(\Delta) ; 105(\odot)$ and $120 \mathrm{~min}(\square)$.

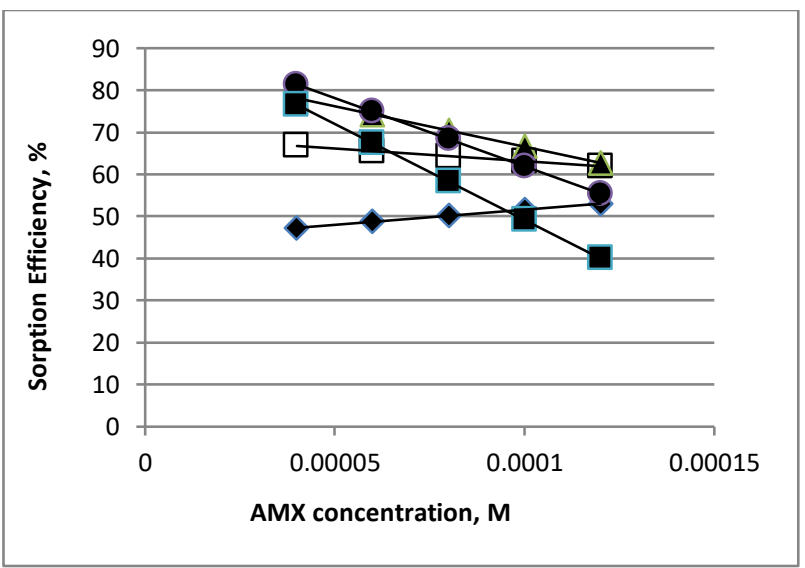

Figure 9. The effect of AMX concentration of the sorption efficiency after $90 \mathrm{~min}$ contact time using WTR contents of $2(\diamond) ; 6.5(\square) ; 11(\Delta) ; 15.5$ $(\oplus)$ and $20 \mathrm{~g} / \mathrm{L}(\boldsymbol{\square})$.

Figure 9 shows the effect of AMX concentration of the sorption efficiency at a fixed equilibrium time of $90 \mathrm{~min}$. and various WTR contents. The WTR content is very important to determine the sorption efficiency as a function of concentrations. Only a slight increase in efficiency from 54 up to $62 \%$ could be established at $2 \mathrm{~g} / \mathrm{L}$ WTR content with the triplication of initial concentration from 0.00004 to $0.00012 \mathrm{M}$. The concentration has no significant effect at lower WTR content while the combination of low concentration with high WTR content gave the highest sorption values (85\%) but sharply decreases down to less than $50 \%$ with the increase in concentration up to $0.00012 \mathrm{M}$. Pachauri, et al., (13) found that the removal of amoxicillin dropped from $80 \%$ down to $24.2 \%$ when the initial concentration was increased from $200 \mathrm{mg} / \mathrm{L}$ up to $1000 \mathrm{mg} / \mathrm{L}$ through GAC column. 


\section{Conclusion:}

Water treatment residue proved successful and rather cheap sorbent with cation exchange capacity of $20.63 \mu \mathrm{mole} / \mathrm{g}$ as been determined using MB adsorption. The material could be used successfully for the removal of AMX from wastewater. The sorption efficiency of the process is significantly affected by the initial antibiotic concentration being better for lowering the AMX concentration. The optimum WTR content was 15.5 g. $\mathrm{L}^{-1}$. The process is relatively fast and 90 minutes contact time was found adequate for the removal of $90 \%$ of the antibiotic from water using a sorbent content of about $15.5 \mathrm{~g} / \mathrm{L}$.

\section{Acknowledgement:}

The authors are grateful to Mr. Thamir Adnan, Mr. Hassan Hadi and Dr. Bashar Hussain for their invaluable assistance in the experimental section of the work.

\section{Authors' declaration:}

- Conflicts of Interest: None.

- We hereby confirm that all the Figures and Tables in the manuscript are mine ours. Besides, the Figures and images, which are not mine ours, have been given the permission for re-publication attached with the manuscript.

- Ethical Clearance: The project was approved by the local ethical committee in University of Technology.

\section{References:}

1. Sköld O. Antibiotics and Antibiotics Resistance New Jersey (USA): Wiley 2011: pp 207.

2. Centers for Diseases Control. Antibiotic Resistance Threats in the United States. 2019; 24/7, https://www.cdc.gov/drugresistance/biggestthreats.html.

3. Diwan V, Hanna N, Purohit M, Chandran S, Riggi E, Parashar V. Seasonal Variations in Water-Quality, Antibiotic Residues, Resistant Bacteria and Antibiotic Resistance Genes of Escherichia coli Isolates from Water and Sediments of the Kshipra River in Central India, Int J Environ Res Public Health. 2018; 15(6): 1281.

4. Lindsey ME, Meyer M, Thurman E. Analysis of trace levels of sulfonamide and tetracycline antimicrobials in groundwater and surface water using solid-phase extraction and liquid chromatography/ mass spectrometry. Anal. Chem. 2001; 73(19): 4640-4646.

5. Danner M-C, Roberson A, Behrends V, Reiss J. Antibiotic pollution in surface fresh waters: Occurrence and effects. Sci. Total Environ. 2019; 644: 793-804

6. Michael I, Rizzo L, McArdell CS, Manaia CM, Merlin C, Schwartz Dagot TC, et al. Urban wastewater treatment plants as hotspots for the release of antibiotics in the environment: a review. Water Res. 2013; 47(3): 957-995.

7. Chen K, Zhou J. Occurrence and behavior of antibiotics in water and sediments from the Huangpu River, Shanghai, China. Chemosphere. 2014; 95: 604-612.

8. Li SW, Hsiang Wang Y, Yu-Chen Lin A. Ecotoxicological effect of ketamine: Evidence of acute, chronic and photolysis toxicity to Daphnia magna. ECOTOX ENVIRON SAFE, Sept. 2017

9. Barbooti MM. Role of organic matter, clay, and iron contents in the sorption of oxytetracycline on river sediments Environ. Health Eng. Manage. J. 2017; 4(2): 109-115

10. Yang G, Bao D, Zhang A, Wang C, Qu L, Li H. Removal of antibiotics from water with an all-carbon 3D nanofiltration membrane. Nanoscale Res. Lett. 2018; 13: 146.

11. Watkinson A, Murby E, Costanzo S. Removal of antibiotics in conventional and advanced wastewater treatment: implications for environmental discharge and wastewater recycling. Water Res. 2007; 41(18): 4164-4176.

12. Mehrjouei M, Müller S, Möller D. Energy consumption of three different advanced oxidation methods for water treatment: a cost-effectiveness study. J. Cleaner Prod. 2014; 65, 178-183.

13. Pachauri P, Falwariya R, Vyas S, Maheshwari Vyas M, Gupta AB. Removal of Amoxicillin in Wastewater Using Adsorption by Powdered and Granular Activated Carbon and Oxidation with Hydrogen Peroxide. Nature, Environ. Poll. Technol. 2009; 8 (3): 481-488.

14. Genç N, Dogan, EC. Adsorption kinetics of the antibiotic ciprofloxacin on bentonite, activated carbon, zeolite, and pumice. DESALIN WATER TREAT. 2015; 53(3): 785-793

15. Dehghan A, Hadi M, Dehghani R, Navid N, Nabizadeh R, Ramezanian N, et al. Adsorption and visible-light photocatalytic degradation of tetracycline hydrochloride from aqueous solutions using 3D hierarchical mesoporous BiOI: Synthesis and characterization, process optimization, adsorption and degradation modeling. Chem. Eng. Res. Design. 2018; 129: 217-230

16. Zhou Q, Li Z, Shuang C, Li A, Zhang M, Wang M. Efficient removal of tetracycline by reusable magnetic microspheres with a high surface area. Chem. Eng. J. 2012; 210: 350-356.

17. Barbooti MM, Su H, Punamiya P, Sarkar D. Oxytetracycline sorption onto Iraqi montmorillonite. Int. J. Environ. Sci. Technol. 2014; 11 (1): 69-76.

18. Aksu, Z, Tunc O. Application of biosorption for penicillin $G$ removal: comparison with activated carbon. Process Biochem. 2005; 40 (2) 831-847.

19. Alexander JA, Zaini MA, Surajudeen A, Aliyu EU, Omeiza AU. Surface modification of low-cost bentonite adsorbents-A review Particulate Science and Technology. 2019, 37(5): 538-549.

20. Balarak D, Joghatayi A, Mostafapour FK, Azarpira H. Biosorption Of Amoxicillin From Contaminated 
Water Onto Palm Bark Biomass. Int. J. Life Sciences and Pharm Res. 2017; 7(1) L-9-L-16.

21. Tovar CT, Ortíz AV, Avila AC, Acevedo D, Gómez NP. Kinetics and Modeling of Drug Adsorption using Activated Carbon Derived from Cocoa Cob Waste Int. J. Chem. Technol. Res. 2018; 11(5): 149-160.

22. Boukhelkhal A, Benkortbi O, Hamadache M, Ghalem N, Hanini S. Mass transfer and adsorption of amoxicillin from wastewater using wheat grain. Proc. $14^{\text {th }}$ Inter. Conf. Environ. Sci. Technol. 2015; Rhodes, Greece.

23. Maia GS, Andrade JR, Oliveira MF, Vieira MGA, da Silva MGC. Affinity Studies between Drugs and Clays as Adsorbent Material. Chem. Eng. Trans. 2017; 57: 2017

24. Song Y. The adsorption of amoxicillin by mesoporous silica supported polymers. M. Sc. Thesis, Rutgers University, 2018.

25. Moradi SE. Highly Efficient Removal of Amoxicillin from Water by Magnetic Graphene Oxide Adsorbent. Chem. Bull. Politeh. Univ. of Timisoara, Romania. 2015; 60(74), 2: 41-48.

26. Maichin F, Freitas LC, Ortiz N. The use of converter slag (magnetite) and bentonite clay for amoxicillin adsorption from polluted water. Orbital: Electronic J. Chem. 2013; 5 (3): 213-217

27. De Gisi S, Lofrano G, Grassi M, Notarnicola M. Characteristics and adsorption capacities of low-cost sorbents for wastewater treatment: A review. Sustainable Mater. Technol. 2016; 9: 10-40

28. Lee LY, Wang B, Guo H, Hu JY, Ong SL. Aluminum-based water treatment residue reuse for phosphorus removal. Water.2015; 7: 1480-1496; doi:10.3390/w7041480.

29. Wolowiec M, Komorowska-Kaufman M, Pruss A., Rzepa G, Bajda T. Removal of heavy metals and metalloids from water using drinking water residues as adsorbents: A review. Minerals. 2019: 9:487-503.

30. Punamiya P, Pigna M, Violante A, Sarkar D. Effect of particle size of drinking-water treatment residuals on the sorption of arsenic in the presence of competing ions. J. Hazard. Mater. 2013; 260: 644-51

31. Suda A, Baba K, Akahane I, Makino T. Use of water - treatment residue containing polysilicate-iron to stabilize arsenic in flooded soils and attenuate arsenic uptake by rice (Oryza sativaL.) Plants. Soil Sc. Plant Nutr. 2016; 62(2): 111-116,

32. Zhao Y, Wang C, Wendling LA, Pei Y. Feasibility of Using Drinking WTR as a Novel Chlorpyrifos Adsorbent. J. Agric. Food Chem. 2013; 61(31): 7446-7452. DOI: 10.1021/jf401763f.

33. Fan J, He Z, Ma L. Q, Yang Y, Stoffella P.J. Impacts of calcium water treatment residue on the soil-waterplant system in citrus production. Plant Soil. 2014, 374: 993-1004. DOI 10.1007/s11104-013-1881-z.

34. Barbooti MM, Hasan SS, Jassim M. Evaluation of water treatment residue as a sorption medium and its application to control phosphate level in water. Eng. Technol. J. 2019; 37 C(1) 126-131.

35. Kahr G, Madsen FT. Determination of the cation exchange capacity and the surface area of bentonite, illite and kaolinite by methylene blue adsorption. Appl. Clay Sci. 1995; 9: 327-336.

36. Lawson J. Design and analysis of experiments with SAS. CRC Press, Boca Rato, 2009 Fl. DOI: $10.1007 / \mathrm{s} 13762-018-2067-2$.

37. Barbooti MM, Al-Dabbagh BD, Hilal RH. Preparation, characterization and utilization of polyacrylic acid-kaolin composite in the removal of heavy metals from water. Int. J. Environ. Sci. Technol. 2019; 16: 4571-4582.

38. Taher T, Lesbani A. Adsorption of Procion Red on Natural Bentonite: Kinetic Studies. Orlwyaya J. Environ. 2016; 1(1):1-4.

39. Ippolito JA, Barbarick KA, Heil DM, Chandler JP, Redente EF. Phosphorus retention mechanisms of a water treatment residual. J. Environ. Qual. 2003; 32:1857-1864.

40. Makris KC, Harris WG, O’Connor GA, Obreza TA. Phosphorus immobilization in micropores of drinking-water treatment residuals: Implications for long-term stability. Environ. Sci. Technol. 2004; 38:6590-6596.

41. Vijayalakshmi G, Ramkumar B, Chandra Mohan S. Kinetics and Equilibrium Study for the Adsorption of Methylene Blue Dye on Azadiratchaindica Activated Carbon. Int Res J. Appl. Sci. 2019; 1(3): 91-99. 
إزالة الاموكسيسيلين من الماء بالامتزازعلى مخلفات معالجة المياه

$$
\text { سارة هادي زهراو }
$$

محمود مهـي بربوتي

قسم العلوم التطبيقية، الجامعة التكنولوجية، بغداد، العر اق.

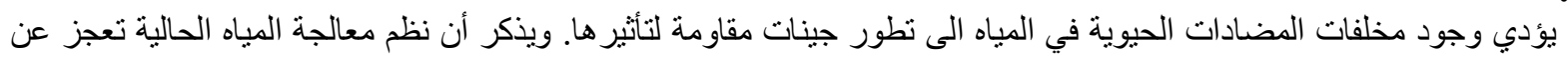

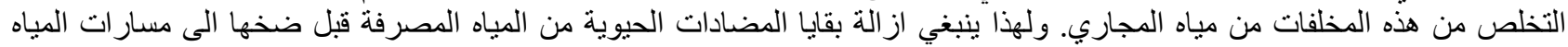

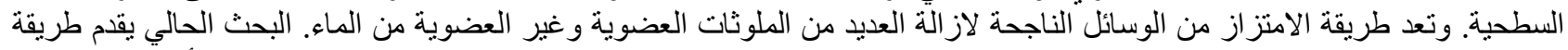

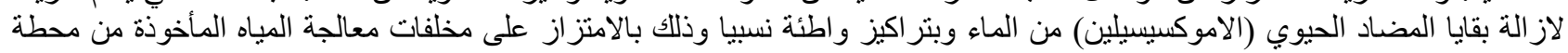

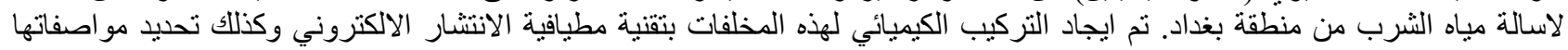

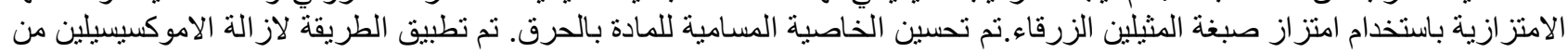

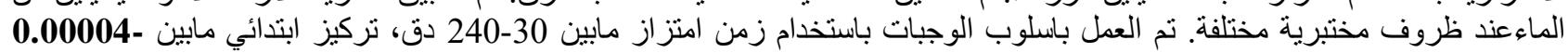

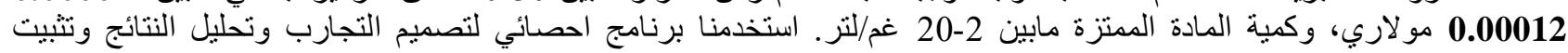

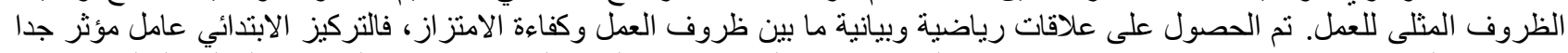

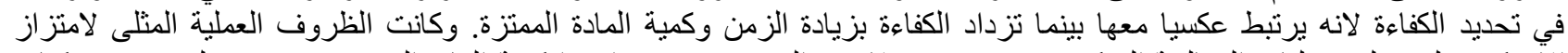
الأموكسيسيلين على مخلفات المعالجة التركيز:

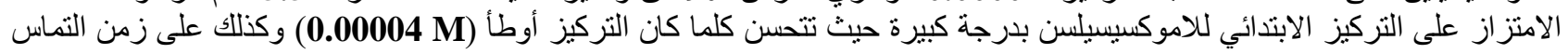
مع المادة الممتزة (100 دقيقة). الكلمات المفتاحية: الامتز از، الأموكسيسيلين، إز الة المضادات الحيوية، التصميم التجريبي، بقايا معالجة المياه الزرقاء بالميثيلين. 